Further Investigations of High Temperature Knitted Spring Tubes for Advanced Control Surface Seal Applications

Shawn C. Taylor and Jeffrey J. DeMange

University of Toledo, Toledo, Ohio

Patrick H. Dunlap, Jr. and Bruce M. Steinetz

Glenn Research Center, Cleveland, Ohio 


\section{NASA STI Program . . . in Profile}

Since its founding, NASA has been dedicated to the advancement of aeronautics and space science. The NASA Scientific and Technical Information (STI) program plays a key part in helping NASA maintain this important role.

The NASA STI Program operates under the auspices of the Agency Chief Information Officer. It collects, organizes, provides for archiving, and disseminates NASA's STI. The NASA STI program provides access to the NASA Aeronautics and Space Database and its public interface, the NASA Technical Reports Server, thus providing one of the largest collections of aeronautical and space science STI in the world. Results are published in both non-NASA channels and by NASA in the NASA STI Report Series, which includes the following report types:

- TECHNICAL PUBLICATION. Reports of completed research or a major significant phase of research that present the results of NASA programs and include extensive data or theoretical analysis. Includes compilations of significant scientific and technical data and information deemed to be of continuing reference value. NASA counterpart of peer-reviewed formal professional papers but has less stringent limitations on manuscript length and extent of graphic presentations.

- TECHNICAL MEMORANDUM. Scientific and technical findings that are preliminary or of specialized interest, e.g., quick release reports, working papers, and bibliographies that contain minimal annotation. Does not contain extensive analysis.

- CONTRACTOR REPORT. Scientific and technical findings by NASA-sponsored contractors and grantees.
- CONFERENCE PUBLICATION. Collected papers from scientific and technical conferences, symposia, seminars, or other meetings sponsored or cosponsored by NASA.

- SPECIAL PUBLICATION. Scientific, technical, or historical information from NASA programs, projects, and missions, often concerned with subjects having substantial public interest.

- TECHNICAL TRANSLATION. Englishlanguage translations of foreign scientific and technical material pertinent to NASA's mission.

Specialized services also include creating custom thesauri, building customized databases, organizing and publishing research results.

For more information about the NASA STI program, see the following:

- Access the NASA STI program home page at http://www.sti.nasa.gov

- E-mail your question via the Internet to help@sti.nasa.gov

- Fax your question to the NASA STI Help Desk at 301-621-0134

- Telephone the NASA STI Help Desk at 301-621-0390

- Write to:

NASA STI Help Desk

NASA Center for AeroSpace Information 7121 Standard Drive Hanover, MD 21076-1320 
NASA/TM-2006-214348

AIAA-2005-4154

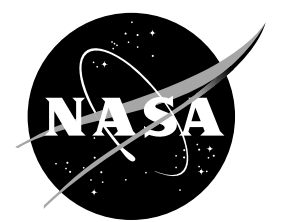

\section{Further Investigations of High Temperature Knitted Spring Tubes for Advanced Control Surface Seal Applications}

Shawn C. Taylor and Jeffrey J. DeMange

University of Toledo, Toledo, Ohio

Patrick H. Dunlap, Jr. and Bruce M. Steinetz

Glenn Research Center, Cleveland, Ohio

Prepared for the

41st Joint Propulsion Conference and Exhibit cosponsored by the AIAA, ASME, SAE, and ASEE

Tucson, Arizona, July 10-13, 2005

National Aeronautics and

Space Administration

Glenn Research Center

Cleveland, Ohio 44135 


\section{Acknowledgments}

The authors wish to acknowledge Dr. Joseph Prahl and Dr. Robert Mullen of Case Western Reserve University for their guidance and support during this project. The authors also extend their gratitude to Pete Kantzos of the

Ohio Aerospace Institute for his assistance with metallography work.

Trade names and trademarks are used in this report for identification only. Their usage does not constitute an official endorsement, either expressed or implied, by the National Aeronautics and Space Administration.

Level of Review: This material has been technically reviewed by technical management.

Available from

NASA Center for Aerospace Information 7121 Standard Drive

Hanover, MD 21076-1320
National Technical Information Service 5285 Port Royal Road Springfield, VA 22161 


\title{
Further Investigations of High Temperature Knitted Spring Tubes for Advanced Control Surface Seal Applications
}

\author{
Shawn C. Taylor and Jeffrey J. DeMange \\ University of Toledo \\ Toledo, Ohio 43606 \\ Patrick H. Dunlap, Jr. and Bruce M. Steinetz \\ National Aeronautics and Space Administration \\ Glenn Research Center \\ Cleveland, Ohio 44135
}

\begin{abstract}
Knitted metallic spring tubes are the structural backbones that provide resiliency in control surface seals for use on current and future reusable space launch vehicles. Control surface seals fill the space between movable control surfaces such as body flaps, rudders and elevons, and the static body structures to which they are attached. These seals must remain in continuous contact with opposing surfaces to prevent the ingestion of damaging hot gases encountered during atmospheric re-entry. The Inconel X-750 spring tube utilized in the baseline control surface seal shows significant resiliency loss when compressed at temperatures as low as $1200{ }^{\circ} \mathrm{F}$. High temperature compression testing and microstructural analysis show that creep is the dominant deformation mechanism leading to permanent set and resiliency loss in tested spring tube samples. Additional evaluation using a structured design of experiments approach shows that spring tube performance, primarily high temperature resiliency, can be enhanced through material substitution of Rene 41 alloy (for the baseline Inconel X-750 material) when coupled with specialized thermal processing.
\end{abstract}

\section{Introduction}

Reusable launch vehicles and other space exploration craft utilize movable panels known as control surfaces to attain a desired trajectory during flight. Common control surfaces include rudders, body flaps, and elevons. During atmospheric re-entry, leakage of hot gases through gaps where these actuated control surfaces interface with static structural surfaces (e.g., fin sections) can damage underlying temperatureintolerant systems such as the mechanical actuators responsible for vehicle navigation. Damage to these structures during flight could have detrimental effects on guidance, and lead to the catastrophic loss of both vehicle and crew. To prevent such occurrences, control surface seals are installed to seal the gaps between static sections and the actuated panels, thereby inhibiting the penetration of high temperature gases. Control surface seals must withstand the extreme environmental conditions experienced during re-entry and perform reliably through multiple heat and load cycles. Fig. 1 illustrates a typical application of control surface seals on the proposed X-38 Crew Return Vehicle.

As space exploration and flight technologies continuously evolve, performance requirements placed upon vehicle components become more demanding. Higher craft velocities and thinner external panels lead to increased exposure temperatures during re-entry for critical systems like control surface actuators. To accommodate these elevated temperatures and facilitate the proper function of vehicle systems, advancements 
in sealing technology must be consistently achieved. The NASA Glenn Research Center (GRC) and The University of Toledo (UT) are working in collaboration to develop and test advanced control surface seals and seal components to address this dynamic need.

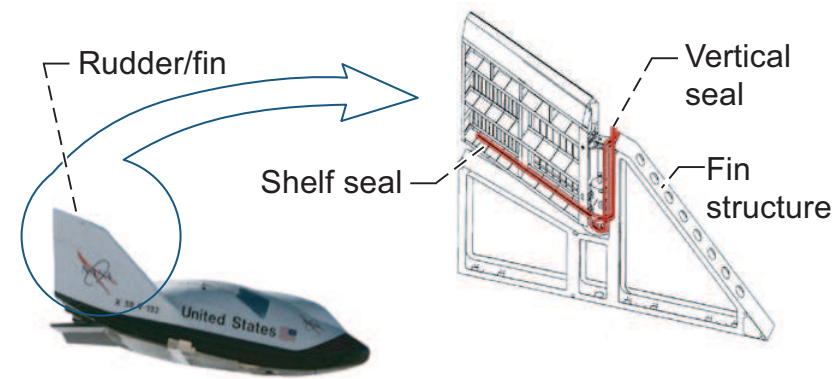

Figure 1. Schematic of the X-38 CRV rudder/fin structure showing typical seal locations.

\section{A. Control Surface Seal Design Requirements}

The hostile nature of the re-entry environment that future space vehicles will need to endure generates a stringent set of design requirements for next generation control surface seals. To ensure vehicle structural integrity, seals must be capable of surviving at predicted temperatures as high as 1800 to $2200{ }^{\circ} \mathrm{F}$, while restricting the leakage of hot gases to underlying temperature sensitive components. Control surface seals are typically installed in a compressed state, e.g., $20 \%$ of their nominal diameter, to compensate for both expansions and contractions of the gaps in which they are installed. To be effective, seals must maintain sufficient resiliency to remain in constant contact with opposing surfaces throughout multiple high temperature exposures and compressive cycles. Failure to satisfy this requirement would establish a direct path for leakage of damaging hot gases to underlying structures. In addition, surfaces such as Space Shuttle tiles cannot sustain high compressive loads, and as a result, seals must be designed to limit applied contact forces. Seal design requirements are outlined in Table 1. The goal of researchers at UT and NASA GRC is to develop control surface seal designs that can adequately accommodate all of these requirements.

\begin{tabular}{|l|c|}
\hline \multicolumn{1}{|c|}{ Parameter } & Design Requirement \\
\hline $\begin{array}{l}\text { Seal } \\
\text { temperature }\end{array}$ & $\begin{array}{c}\text { Between } 1800^{\circ} \mathrm{F} \text { and } 2200{ }^{\circ} \mathrm{F} \\
\text { depending on vehicle application }\end{array}$ \\
\hline Maximum unit loads & $5 \mathrm{lbf} /$ in.-Shuttle tile ${ }^{1}$ \\
\hline Environment & Oxidizing environment \\
\hline Time at maximum temperature & 1000 sec. to 2200 sec. $^{1}$ \\
\hline Size & 0.5 to 1.0 in. nominal diameter \\
\hline Reusability & TBD-nominally 10 to 100 cycles \\
\hline Resiliency & Accommodate seal gap openings and closings \\
\hline Seal gap size & Nominally 0.25 in. \\
\hline
\end{tabular}

Table 1. Control Surface Seal Design Requirements

\section{B. Baseline Control Surface Seal and Previous Testing}

The current baseline control surface seal design was selected for use on the X-38, and is derived from Space Shuttle thermal barriers having a nearly identical configuration, but varying in size. On the Shuttle, these thermal barriers are positioned around the main landing gear doors, the orbiter external tank umbilical door, and the payload bay door vents (Fig. 2). In these locations, the thermal barriers are used to shield underlying temperature sensitive components from excessive heat transfer, and also to prevent hot gas ingestion at the mating sections of the movable panels. 

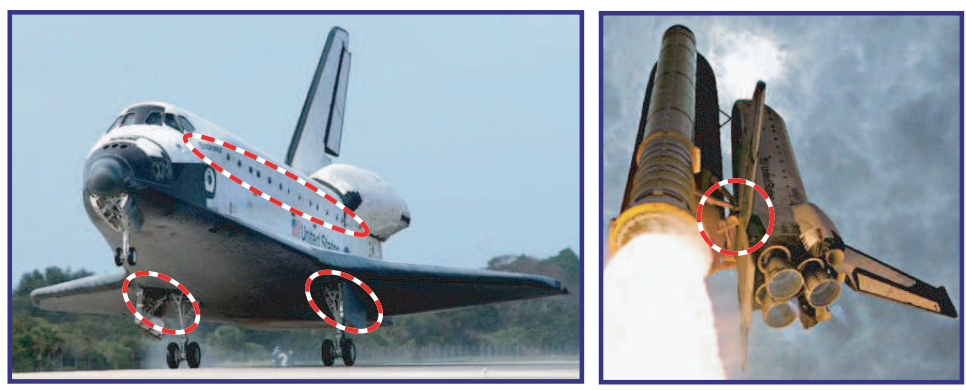

Figure 2. Highlighted photographs show typical locations of the baseline seal on the Space Shuttle.

As shown in Fig. 3, the baseline control surface seal is comprised of three components: 1.) A 2-layer Nextel 312 (3M, St. Paul, MN) sheath 2.) An Inconel X-750 (Special Metals Corp., Huntington, WV) spring tube 3.) A Saffil (Saffil Ltd., Cheshire, UK) core. The primary source of resiliency in the baseline design is the Inconel X-750 spring tube (0.560 in. nominal diameter) which acts as the structural backbone of the seal. The spring tube is fabricated by knitting three parallel strands of Inconel X-750 wire using a repeating looped pattern to form an open ended tube. The baseline spring tube knit geometry is herein referred to as the ST-5 knit geometry

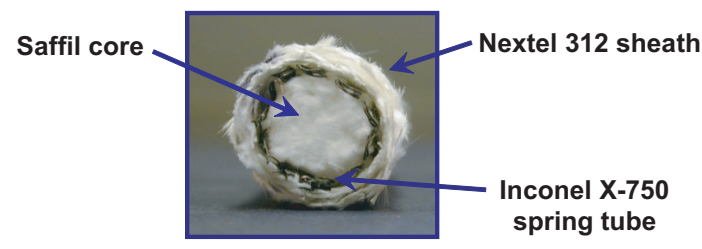
as prescribed in Boeing specification MB0160-047. ${ }^{2}$ The

Figure 3. Photograph illustrating the three components of the baseline control surface seal design.

ST-5 geometry is described by a set of numerical parameters which includes: number of wire strands, courses per inch (CPI), needles $(\mathrm{N})$, wire diameter, and spring tube major diameter $(\mathrm{D})$. These parameters are presented graphically in Figure 4 and are defined as follows:

Number of wire strands - the number of individual wires knitted simultaneously in a parallel configuration to form the spring tube,

CPI - the number of individual loops (lengthwise) per inch of spring length,

$\mathbf{N}$ - the number of individual contiguous loops counted along a single rotation about the circumference of a spring tube,

Wire diameter - the diameter of the individual wire strands used in fabrication, and

D - the outer diameter of the spring tube.

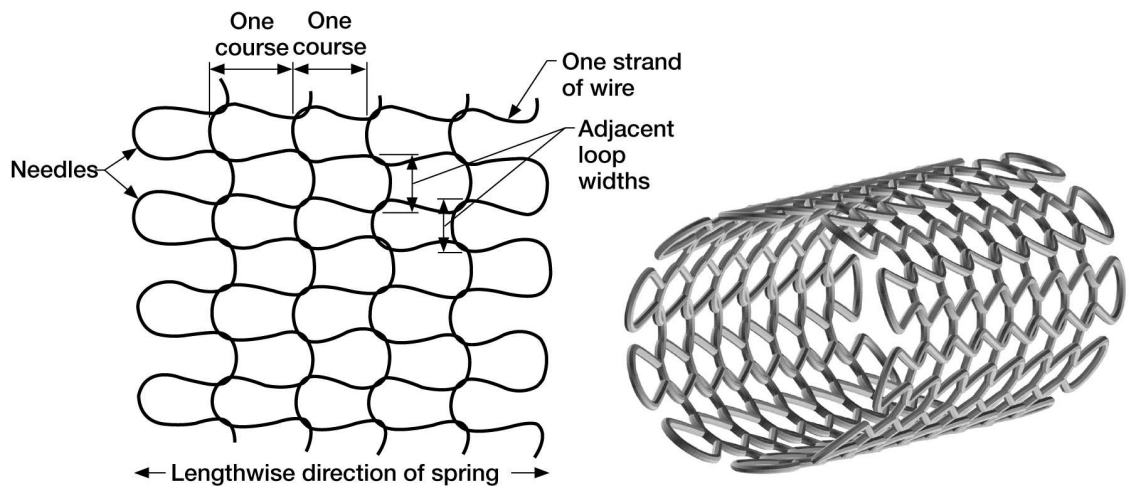

Figure 4. Schematic illustrating spring tube parameters (left) and computer generated image depicting the 3-dimensional spring tube geometry (right). 
Loop density (LD) is used to simplify the comparison of spring tube designs having different knit geometries. Loop density is an estimation of the number of individual loops per square inch of spring tube surface area. The value can be visually determined by inspection, or it can be found numerically using the following equation:

$$
L D \equiv \frac{C P I \bullet N}{\pi \bullet D} \quad\left[\frac{\text { loops }}{\text { in. }^{2}}\right]
$$

The ST-5 design is fabricated using three strands of 0.009 in. dia. wire which are knitted into a $0.560 \pm$ 0.025 in. dia. spring tube with $10 \mathrm{~N}, 4.9 \mathrm{CPI}$, and an LD of 28 loops per in. ${ }^{2}$. Once knitted, the spring tube is heat treated per Aerospace Material Specification (AMS) 5698 for a number one temper wire to improve the strength properties of the Inconel alloy. ${ }^{3}$

Results from previous compression tests on the baseline control surface seal at $1900^{\circ} \mathrm{F}$ show a significant loss of resiliency and a large permanent set in the seal (Fig. 5). ${ }^{4}$ This resiliency loss is attributed to decreased yield strength of the Inconel X-750 spring tube component at the elevated test temperature. Similar results are observed when the Inconel spring tube is tested by itself. ${ }^{5}$ Further testing of the Inconel ST5 at multiple temperatures shows noticeable resiliency loss and permanent set when samples are compressed above $1200^{\circ} \mathrm{F}$. This resiliency decrease nearly mirrors the temperature dependent yield strength behavior of Inconel $\mathrm{X}-750$. Despite this evidence that time independent

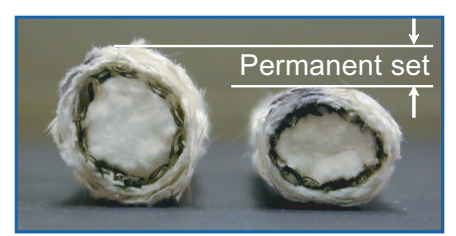

Figure 5. Photograph of baseline seal before (left) and after (right) compression during 1900 ${ }^{\circ} \mathrm{F}$ exposure showing seal resiliency loss. Initial seal dia. is approximately $0.62 \mathrm{in}$. plastic flow (due to decreased Inconel yield strength with temperature) is primarily responsible for resiliency loss in the baseline seal, creep deformation is also suspected to play a significant role at the high test temperatures. However, further evaluation is required to isolate the dominant deformation mechanism.

In addition to testing of the baseline spring tube, a preliminary set of screening tests on modified spring tube designs conducted at NASA GRC confirmed that both material substitution (including heat treatment) and modification of the knit geometry pattern can be used to enhance high temperature spring tube performance. Although material substitution (heat treated Rene 41 (Allvac, Monroe, NC) for heat treated Inconel X-750) proved to have the most significant impact on improving spring tube resiliency in early tests, both material substitution and geometry modification are viable options for extending the capabilities of the baseline control surface seal. ${ }^{6}$

Based on the results and observations from previous testing, the focus of this study is to first determine the dominant deformation mechanism leading to limited spring tube resiliency at elevated temperatures and then to further evaluate the influence of heat treatment and geometry modification on Rene 41 spring tube performance using a structured design of experiments (DOE) approach.

\section{Test Equipment and Procedures}

To evaluate the influence of design modification on spring tube performance, high temperature cyclic compression tests are conducted at NASA GRC using a state-of-the-art high temperature compression test rig (Fig. 6a). The primary components of the rig include a servohydraulic load frame, an air furnace, and a non-contacting laser extensometer. A thorough description of this test rig can be found in the paper by Dunlap, et al. ${ }^{7}$ 


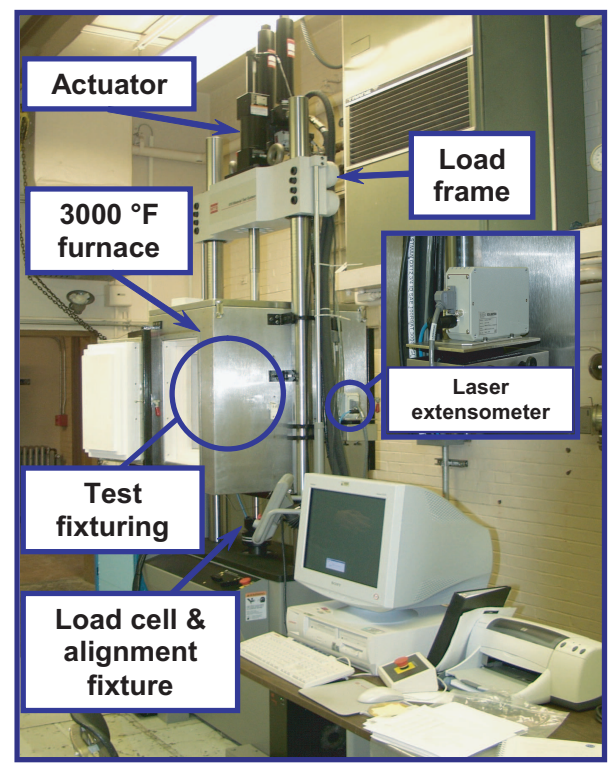

(a) Main components: load frame, air furnace, and non-contacting laser extensometer.

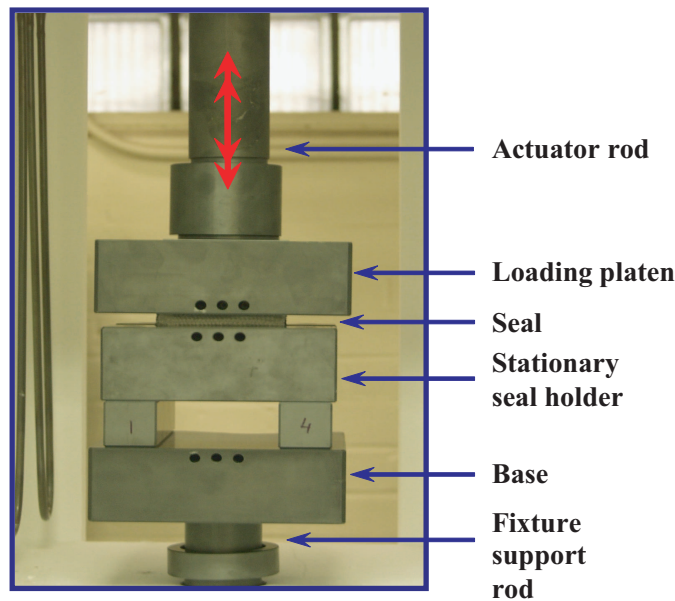

(b) $\mathrm{SiC}$ test fixture.

Figure 6. Photographs of high temperature compression test rig and test fixture.

Spring tubes are cut into 4 in. (nominal) segments for testing. Individual test specimens are supported in a grooved insert ( $0.620 \mathrm{in}$. wide $\mathrm{x} 0.625 \mathrm{in}$. deep, Fig. 7 ) in the stationary seal holder while they are compressed by the loading platen from above (Fig. 6b). This setup is designed to simulate the installed state of a seal on a space vehicle.

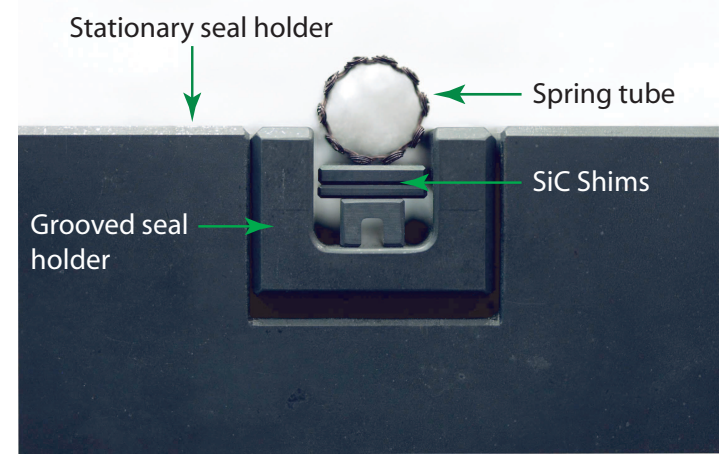

Figure 7. Photograph of the stationary seal holder showing the grooved seal holder insert, SiC shims, and the installed orientation of the spring tube for compression testing. Note that the spring tube shown is filled with cotton to improve image clarity.

At the start of each compression test, the loading platen is lowered until it achieves uniform contact with the test specimen. During hot tests the furnace door is closed, and contact cannot be visually confirmed. For this reason, a nominal spring tube preload of $0.2 \mathrm{lbf}$ is used to define contact between the spring tube sample and the loading platen. Once the preload value is achieved, a new zero deflection point is defined for reference. The spring tube is then deflected $0.112 \mathrm{in.} \mathrm{(20 \%} \mathrm{of} \mathrm{its} \mathrm{nominal} \mathrm{diameter)} \mathrm{relative} \mathrm{to} \mathrm{the} \mathrm{new}$ "reference zero" using a compression rate of 0.002 in. per second. A 250 second dwell period derived from re-entry flight conditions is imposed at maximum deflection, and then the sample is unloaded at the same 
rate. This procedure is repeated until 20 compression cycles are completed. Generated loads are monitored by either a $500 \mathrm{lb}$ load cell calibrated to a $\pm 100 \mathrm{lb}$ range $( \pm 0.15 \mathrm{lb}$ accuracy) or a $100 \mathrm{lb}$ load cell calibrated to $\mathrm{a} \pm 50 \mathrm{lb}$ range $( \pm 0.05 \mathrm{lb}$ accuracy), and the compressive stroke of the loading platen is tracked by the laser extensometer with an accuracy of \pm 0.00025 in.

\section{Data Analysis}

Compression test results are presented in terms of residual interference. Residual interference is a relative measure of the post deflection spring back (resiliency) of a seal or seal component for a given compression stroke length. The value is reported at the start of a specified compression cycle and is most commonly reported as a percentage of the stroke length. Percent residual interference is calculated using the following equation:

$$
\hat{\Gamma}_{n} \equiv\left(\frac{\Delta_{n-1}-\delta_{n}}{\Delta_{n-1}}\right) \bullet 100 \quad[\%]
$$

where $\hat{\Gamma}_{n}$ is the percent residual interference at the start of cycle $\mathrm{n}, \Delta_{n-1}$ is the compressive stroke applied by the loading platen during cycle $n-1$, and $\delta_{n}$ is the permanent set present in the sample at the start of cycle

n. ${ }^{6}$ Schematic and graphical representations of these values are presented in Fig. 8 to clarify the process of calculating the residual interference at the beginning of compression cycle two. A residual interference of $100 \%$ means that a test specimen has taken on no permanent set due to previous compressions. Conversely, a residual interference of $0 \%$ signifies that the test sample has suffered a permanent set at least as large as the displacement of the previous compressive stroke, and all resiliency within that compression range has been lost. Residual interference values presented in this study are accurate to within $2 \%$ (\% residual interference) of the reported value. 

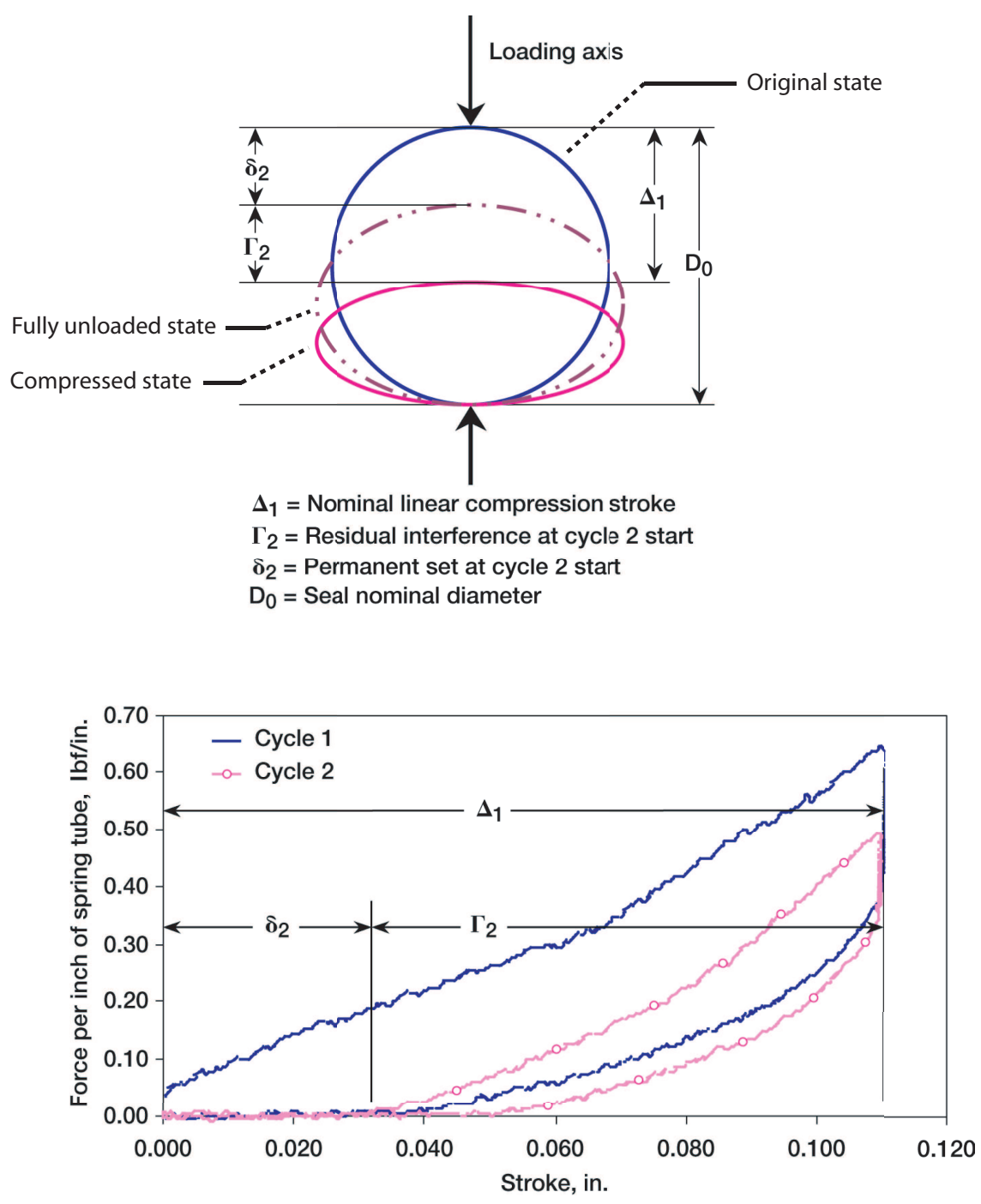

Figure 8. Spring tube schematic illustrating the determination of residual interference at the start of cycle 2 (top) and the corresponding plot of load vs stroke (bottom).

\section{Determination of Dominant Deformation Mechanism}

Before fabricating new spring tube designs with modified geometries and heat treatments, the dominant deformation mechanism producing observed resiliency losses in test samples at elevated temperatures needed to be identified. With this insight, new specimens could be designed accordingly. In an effort to isolate the individual effects of creep deformation and time independent plastic flow, the compression test method typically used for spring tube evaluation was modified to minimize time effects. By eliminating dwell periods and increasing the load/unload rate from $0.002 \mathrm{in}$. per second to $0.010 \mathrm{in}$. per second, the duration of spring tube compression was reduced and creep deformation was limited. All other test conditions remained unchanged. Two tests were conducted at $1750^{\circ} \mathrm{F}$ using heat treated Rene 41 ST-5 (NASA 5950-R41A heat treatment, Table 2) spring tube samples. Loads generated during compression were monitored using the 500 lb load cell. 


\begin{tabular}{|l|c|c|c|}
\hline \multicolumn{4}{|c|}{ NASA 5950-R41A Heat Treatment } \\
\hline $\begin{array}{l}\text { Procedure } \\
\text { Description }\end{array}$ & $\begin{array}{c}\text { Temperature } \\
{\left[{ }^{\circ} \mathrm{F}\right]}\end{array}$ & $\begin{array}{c}\text { Time Duration } \\
{[\mathrm{hrs}]}\end{array}$ & $\begin{array}{c}\text { Cooling } \\
\text { Specification }\end{array}$ \\
\hline $\begin{array}{l}\text { Solution } \\
\text { Treatment }\end{array}$ & 2050 & 0.5 & $\begin{array}{c}\text { Cool to below } 800^{\circ} \mathrm{F} \\
\text { in nitrogen atmosphere }\end{array}$ \\
\hline $\begin{array}{l}\text { Aging Heat } \\
\text { Treatment }\end{array}$ & 1650 & 1 & $\begin{array}{c}\text { Cool to room temp. in } \\
2 \text { hrs. in nitrogen atmosphere }\end{array}$ \\
\hline
\end{tabular}

Table 2. NASA 5950-R41A Heat Treatment for Rene 41 Alloy

As shown in Fig. 9, calculated resiliencies for spring tubes evaluated using the modified compression test method are $2.1 \mathrm{x}$ higher at the start of cycle 10 and $2.5 \mathrm{x}$ higher at the start of cycle 20 when compared to the corresponding resiliencies calculated from standard tests of identical samples. These results provide a strong indication that creep is the dominant deformation mechanism leading to permanent set and resiliency loss in the spring tubes at elevated temperatures.

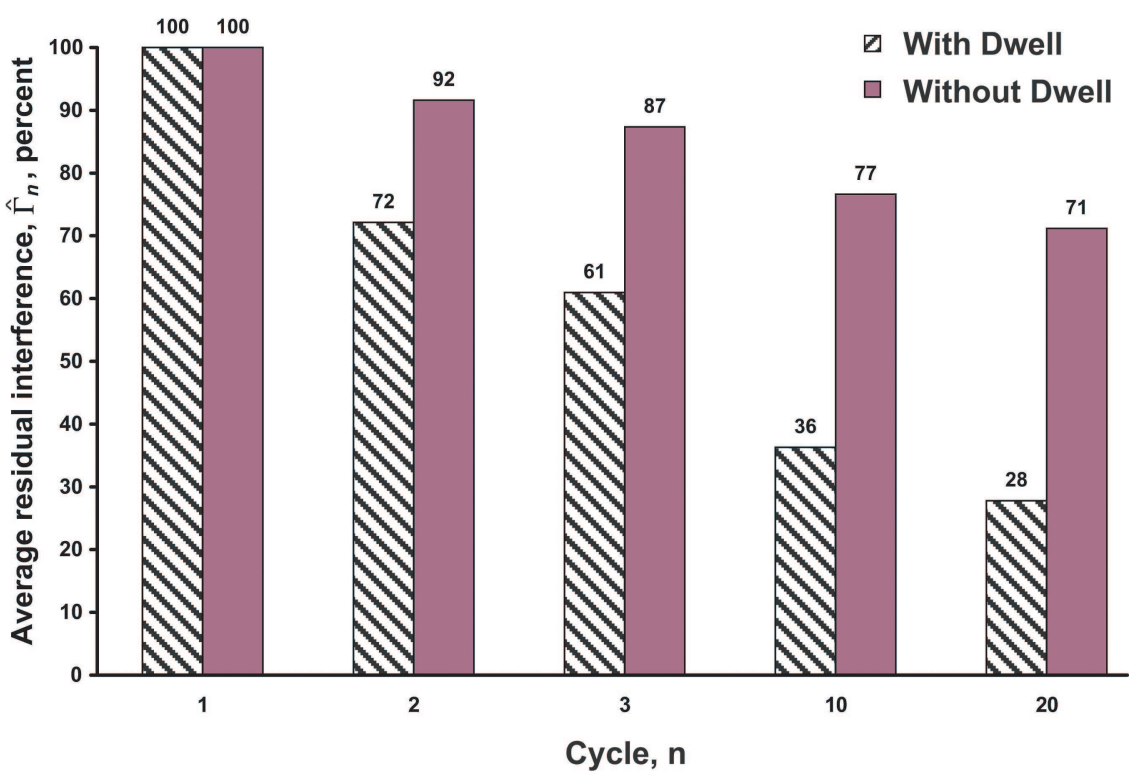

Figure 9. Comparison of average resiliency for multiple compression cycles at $1750{ }^{\circ} \mathrm{F}$ highlighting the influence of creep deformation on spring tube performance. "With Dwell" represents data collected using the standard compression test procedure, and "Without Dwell" represents data collected using the modified test procedure where dwell periods were eliminated and the loading/unloading rate was increased.

To confirm this theory, a microstructure evaluation was conducted. Untested samples of the heat treated Inconel X-750 spring tube (baseline design), the heat treated Rene 41 spring tube (NASA 5950-R41A heat treatment), and the non heat treated Rene 41 spring tube were mounted in epoxy, sectioned, and examined using an optical microscope. A thorough description of this process is presented by Taylor. ${ }^{8}$ As shown in Fig. 10, heat treated Inconel X-750 and non heat treated Rene 41 samples have comparable small grain sizes (10.71 and 11.16, respectively, as calculated per ASTM E112). ${ }^{9}$ These two spring tubes perform similarly during high temperature compression testing, taking on significant permanent set, whereas larger grain, heat treated Rene 41 (7.24 ASTM grain size) spring tubes show significant resiliency improvement. These findings support the theory of creep dominance, as large grain metals are classically better for resisting creep deformation than fine grain alloys. Based on this, improved resiliency may be achieved through modified Rene 41 heat treatments or ODS alloy substitution that would provide an enhanced resistance to creep deformation. 


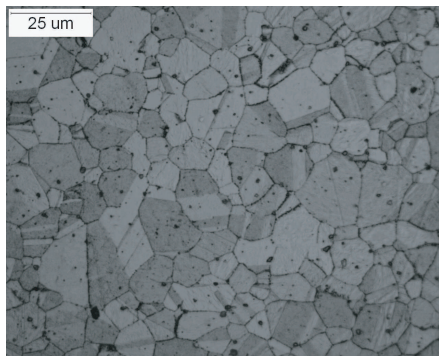

(a) HT Inconel X-750

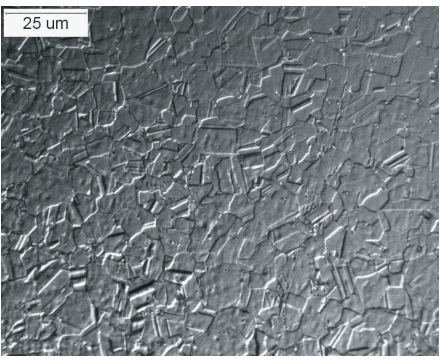

(b) NHT Rene 41

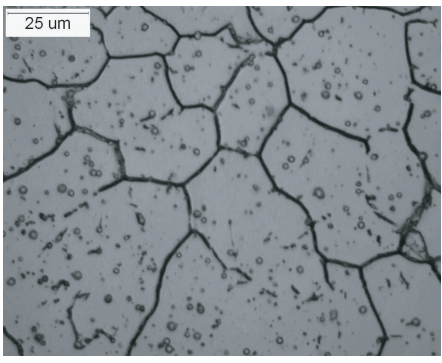

(c) HT Rene 41

Figure 10. Micrographs taken using optical microscopy comparing material grain size.

Further examination of the spring tubes using scanning electron microscopy (SEM) shows that the knitting process produces some surface abrasion on the individual wire strands (Figure 11). Minor surface damage is not believed to be detrimental to metallic samples; however, this could pose an obstacle for future substitution of non-metallic materials such as ceramic fibers that are susceptible to fracture through abrasion.

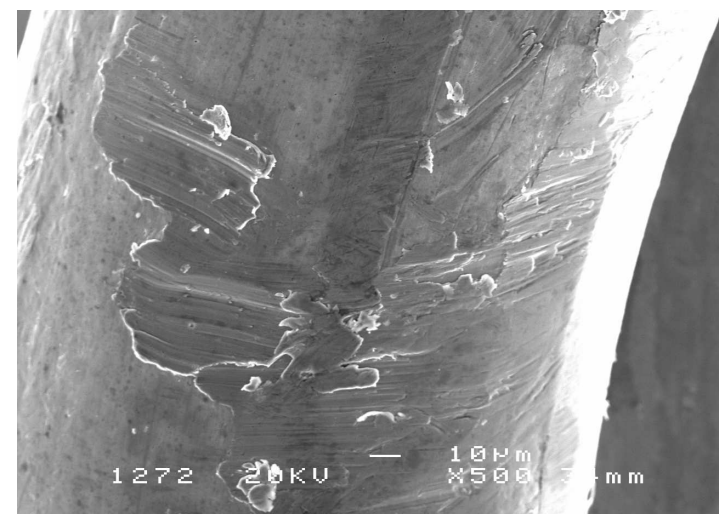

Figure 11. SEM micrograph of an untested non heat treated Rene 41 spring tube showing inherent strand abrasion incurred during knitting.

\section{Spring Tube Design of Experiments Analysis}

\section{A. Background}

To apply the findings of previous spring tube testing and obtain a new design with enhanced performance characteristics, a final round of compression testing was derived using a methodical Design of Experiments (DOE) approach. Three design parameters, loop density, heat treatment, and wire diameter, were selected as test input factors, and spring tube resiliency and peak load were selected as response variables to evaluate factor effects. The three factors and their respective levels are listed in Table 3. 


\begin{tabular}{|l|c|c|}
\hline \multicolumn{3}{|c|}{ Spring Tube DOE Analysis } \\
\hline \multicolumn{1}{|c|}{ Factor } & Level 1 & Level 2 \\
\hline Loop Density [loops/in. ${ }^{2}$ ] & 28 & 136 \\
\hline Heat Treatment & R41A & R41C \\
\hline Wire Diameter [in.] & 0.009 & 0.005 \\
\hline
\end{tabular}

Table 3. Factors and Levels For Spring Tube DOE Analysis

Loop density and heat treatment were selected for further analysis due to their positive impact on spring tube performance in previous effects screening tests. Wire diameter was selected as a test factor because numerical modeling of the spring tube using finite element analysis shows that decreasing wire diameter reduces wire stress, and potentially reduces incurred spring tube permanent set. ${ }^{10}$

Having identified creep as the driving mechanism behind spring tube resiliency loss, a new heat treatment was developed to enhance the high temperature creep resistant properties of Rene 41. This heat treatment is identified as the NASA 5950-R41C heat treatment (Table 4). The solution treatment temperature of 2025 ${ }^{\circ} \mathrm{F} \pm 25^{\circ} \mathrm{F}$ was selected because it is above the gamma prime $\left(\mathrm{Ni}_{3}(\mathrm{Al}, \mathrm{Ti})\right)$ solvus temperature $(1960 / 1980$ $\left.{ }^{\circ} \mathrm{F}\right)$ but below the $\mathrm{M}_{6} \mathrm{C}$ carbide solvus temperature $\left(2100{ }^{\circ} \mathrm{F}\right) \cdot{ }^{11}$ If the $\mathrm{M}_{6} \mathrm{C}$ carbide phase $\left(\mathrm{Mo}_{6} \mathrm{C}\right.$ in Rene $41)$ is dissolved, subsequent temperature exposure in the 1400 to $1600{ }^{\circ} \mathrm{F}$ range produces an $\mathrm{M}_{23} \mathrm{C}_{6}((\mathrm{Cr}$, $\mathrm{Mo}, \mathrm{Fe}, \mathrm{Ni})_{23} \mathrm{C}_{6}$ ) carbide film at the Rene 41 grain boundaries which has negative effects on material strength properties. ${ }^{12}$ Heat treating at $2025^{\circ} \mathrm{F}$ prevents the formation of the carbide boundary film, but still allows intragranular gamma prime precipitates to go into solution. Subsequent rapid cooling of the alloy to below $1200{ }^{\circ} \mathrm{F}$ preserves the homogenous state of the metal achieved through the solution treatment phase. Aging heat at $1400^{\circ} \mathrm{F}$ produces a uniformly distributed matrix of gamma prime precipitates which coarsen throughout the 16 hour process duration. This heat treatment should produce improved creep resistance over the original R41A heat treatment due to an increased volume of larger gamma prime precipitates which strengthen the alloy by inhibiting dislocation movement.

\begin{tabular}{|l|c|c|c|}
\hline \multicolumn{4}{|c|}{ NASA 5950-R41C Heat Treatment } \\
\hline $\begin{array}{l}\text { Procedure } \\
\text { Description }\end{array}$ & $\begin{array}{c}\text { Temperature } \\
{\left[{ }^{\circ} \mathrm{F}\right]}\end{array}$ & $\begin{array}{c}\text { Time Duration } \\
{[\mathrm{hrs}]}\end{array}$ & $\begin{array}{c}\text { Cooling } \\
\text { Specification }\end{array}$ \\
\hline $\begin{array}{l}\text { Solution } \\
\text { Treatment }\end{array}$ & $2025 \pm 25$ & 0.5 & $\begin{array}{c}\text { Cool at } 400{ }^{\circ} \mathrm{F} / \text { min or faster to } \\
\text { below } 1200^{\circ} \mathrm{F} \text { in nitrogen atmosphere }\end{array}$ \\
\hline $\begin{array}{l}\text { Aging Heat } \\
\text { Treatment }\end{array}$ & 1400 & 16 & $\begin{array}{c}\text { Cool to room temp. in } \\
2 \text { hrs. in nitrogen atmosphere }\end{array}$ \\
\hline
\end{tabular}

Table 4. NASA 5950-R41C Heat Treatment For Rene 41

Three different spring tube geometries were fabricated for evaluation (Fig. 12). To statistically analyze the effects of the factors presented in Table 3 using a complete $2^{3}$ full factorial experimental design, four geometries would be fabricated using combinations of the geometry factors loop density and wire diameter. By combining these geometries with the two heat treatments, test data for all of the samples could be evaluated simultaneously using analysis of variance (ANOVA) techniques for a $2^{3}$ full factorial design. ${ }^{13}$ However, due to limited manufacturer capabilities, only three of the necessary geometries could be produced. A 136 LD design could not be knitted from 0.009 in. dia. wire. This required data to be organized and analyzed on a paired-factor basis. Samples of the three geometry designs were heat treated using each of the R41A and R41C heat treatment specifications. The heat treatments were slightly modified from their original state in that argon was substituted for nitrogen as the cooling atmosphere due to gas availability at the heat treating facility. Finalized test specimens are listed in Table 5 with their respective knit parameters, heat treatments, and name designations. Preload values used for compression testing each sample are also listed in the table. Preload values were reduced from the nominal $0.2 \mathrm{lbf} / \mathrm{in}$. for spring tubes with lower stiffness to prevent excessive sample deflection prior to the start of each test. These values were selected at room temperature by visually determining the force needed to achieve uniform contact between each test 
specimen and the loading platen. Tests were conducted at $1750^{\circ} \mathrm{F}$, utilized the $100 \mathrm{lb}$ load cell, and followed the standard procedure for 20 cycle compression tests described previously (0.002 in. per second load/unload rate, 250 second dwell at maximum deflection, etc.). The evaluation of each spring tube design included an initial run plus one replicate run.

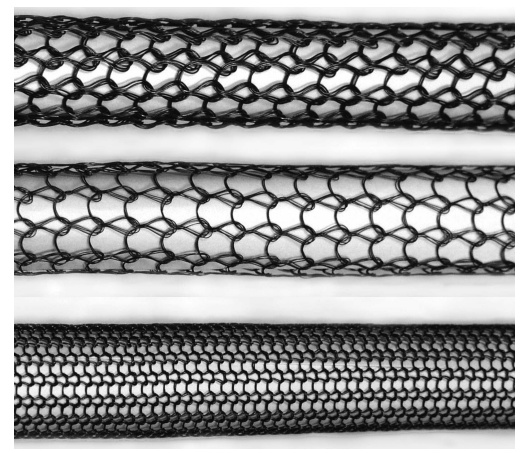

Figure 12. Spring tube knit geometries selected for DOE analysis: Rene ST5 (top), Rene 005-ST5 (center), and Rene 136LD (bottom)

\begin{tabular}{|l|c|c|c|c|c|c|c|}
\hline $\begin{array}{c}\text { Specimen } \\
\text { Identifier }\end{array}$ & $\begin{array}{c}\text { Heat } \\
\text { Treat }\end{array}$ & $\begin{array}{c}\text { Wire } \\
\text { Strands }\end{array}$ & $\begin{array}{c}\text { Wire } \\
\text { Dia. [in. }]\end{array}$ & CPI & N & $\begin{array}{c}\text { LD } \\
{\left[\text { loops/in. }{ }^{2}\right]}\end{array}$ & $\begin{array}{c}\text { Preload } \\
{[\mathrm{lbf} .]}\end{array}$ \\
\hline Rene ST5-A & R41A & 3 & 0.009 & 4.9 & 10 & 28 & 0.2 \\
\hline Rene ST5-C & R41C & 3 & 0.009 & 4.9 & 10 & 28 & 0.2 \\
\hline Rene 005-ST5-A & R41A & 3 & 0.005 & 4.9 & 10 & 28 & 0.05 \\
\hline Rene 005-ST5-C & R41C & 3 & 0.005 & 4.9 & 10 & 28 & 0.05 \\
\hline Rene 136LD-A & R41A & 3 & 0.005 & 15 & 16 & 136 & 0.1 \\
\hline Rene 136LD-C & R41C & 3 & 0.005 & 15 & 16 & 136 & 0.1 \\
\hline
\end{tabular}

Table 5. Experimental Spring Tube Designs For DOE Analysis

\section{B. Results and Discussion}

Compression test results are presented in Table 6 . These results are evaluated using analysis of variance statistical techniques to determine if the selected design factors have a significant impact on spring tube performance. Since a full factorial analysis is not feasible due to test sample fabrication limitations, test data is broken into three groups for analysis. The first group includes test samples Rene 005ST5-A, Rene 005ST5-C, Rene 136LD-A and Rene 136LD-C, and evaluates the effect of heat treatment and loop density on both residual interference and peak load at dwell. The second group includes test samples Rene 005ST5A, Rene 005ST5-C, Rene ST5-A, and Rene ST5-C, and examines the impact of heat treatment and wire diameter on spring tube residual interference and peak load at dwell. Strategic pairing of the first two data groups enables them to be evaluated using a $2^{2}$ full factorial ANOVA. This method facilitates an investigation of not only main factor effects on spring tube performance, but it also allows two factor interaction effects to be examined. The third group includes data from all six spring tube designs and evaluates the overall effect of heat treatment using a one-way ANOVA. The analysis of data collected during the spring tube DOE tests focuses on peak load and residual interference values from cycle 20 because longer term spring tube performance is of primary interest. All analyses applied in this DOE evaluation use a $95 \%$ confidence level to define statistical significance. 


\begin{tabular}{|c|c|c|c|c|c|c|c|c|c|c|}
\hline Specimen Identifier & \multicolumn{9}{|c|}{ Peak load at dwell [lbf/in.] } & \multicolumn{5}{|c|}{$\hat{\Gamma}_{n}$} \\
\hline \hline Cycle, $\mathrm{n}$ & 1 & 2 & 3 & 10 & 20 & 1 & 2 & 3 & 10 & 20 \\
\hline \multirow{2}{*}{ Rene ST5-A } & 0.88 & 0.65 & 0.62 & 0.33 & 0.21 & 100 & 71 & 67 & 45 & 28 \\
\cline { 2 - 13 } & 0.80 & 0.61 & 0.52 & 0.46 & 0.34 & 100 & 69 & 64 & 62 & 36 \\
\hline \multirow{2}{*}{ Rene ST5-C } & 0.60 & 0.44 & 0.38 & 0.23 & 0.22 & 100 & 84 & 70 & 40 & 32 \\
\cline { 2 - 13 } & 0.57 & 0.41 & 0.35 & 0.28 & 0.25 & 100 & 74 & 64 & 52 & 34 \\
\hline \multirow{2}{*}{ Rene 005ST5-A } & 0.09 & 0.06 & 0.05 & 0.03 & 0.02 & 100 & 63 & 55 & 30 & 11 \\
\cline { 2 - 12 } & 0.07 & 0.05 & 0.05 & 0.03 & 0.02 & 100 & 70 & 64 & 29 & 16 \\
\hline \multirow{2}{*}{ Rene 005ST5-C } & 0.07 & 0.05 & 0.04 & 0.03 & 0.04 & 100 & 70 & 66 & 37 & 46 \\
\cline { 2 - 11 } & 0.06 & 0.05 & 0.04 & 0.02 & 0.03 & 100 & 71 & 59 & 36 & 32 \\
\hline \multirow{2}{*}{ Rene 136LD-A } & 0.27 & 0.17 & 0.13 & 0.06 & 0.05 & 100 & 48 & 38 & 16 & 10 \\
\cline { 2 - 11 } & 0.33 & 0.21 & 0.17 & 0.08 & 0.04 & 100 & 55 & 42 & 19 & 9 \\
\hline \multirow{2}{*}{ Rene 136LD-C } & 0.36 & 0.24 & 0.20 & 0.10 & 0.05 & 100 & 60 & 47 & 23 & 11 \\
\cline { 2 - 10 } & 0.41 & 0.27 & 0.20 & 0.23 & 0.08 & 100 & 61 & 47 & 42 & 14 \\
\hline
\end{tabular}

Table 6. Compression Test Results For Spring Tube DOE Analysis

\section{Heat Treatment and Loop Density Effects}

Statistical analysis shows that both heat treatment and loop density have a significant influence on spring tube residual interference at the start of compression cycle 20. The interaction effect between the two factors on resiliency, however, is not significant.

As shown in Figure 13, increasing loop density from 28 loops/in. ${ }^{2}$ to 136 loops/in. ${ }^{2}$ produces a $58 \%$ decrease in cycle 20 residual interference. This is unexpected, as increased loop density in previous effects screening tests shows a moderate resiliency improvement. This trend suggests that there is likely an optimal loop density greater than 28 but less than 136, and once that value is exceeded, spring tube resiliency suffers. The gross loop density increase implemented here results in a large reduction in loop radius. This reduction leads to higher wire stresses, and is likely the cause of the observed resiliency loss. Numerical results from a finite element analysis of the $136 \mathrm{LD}$ design support this conclusion. ${ }^{10}$

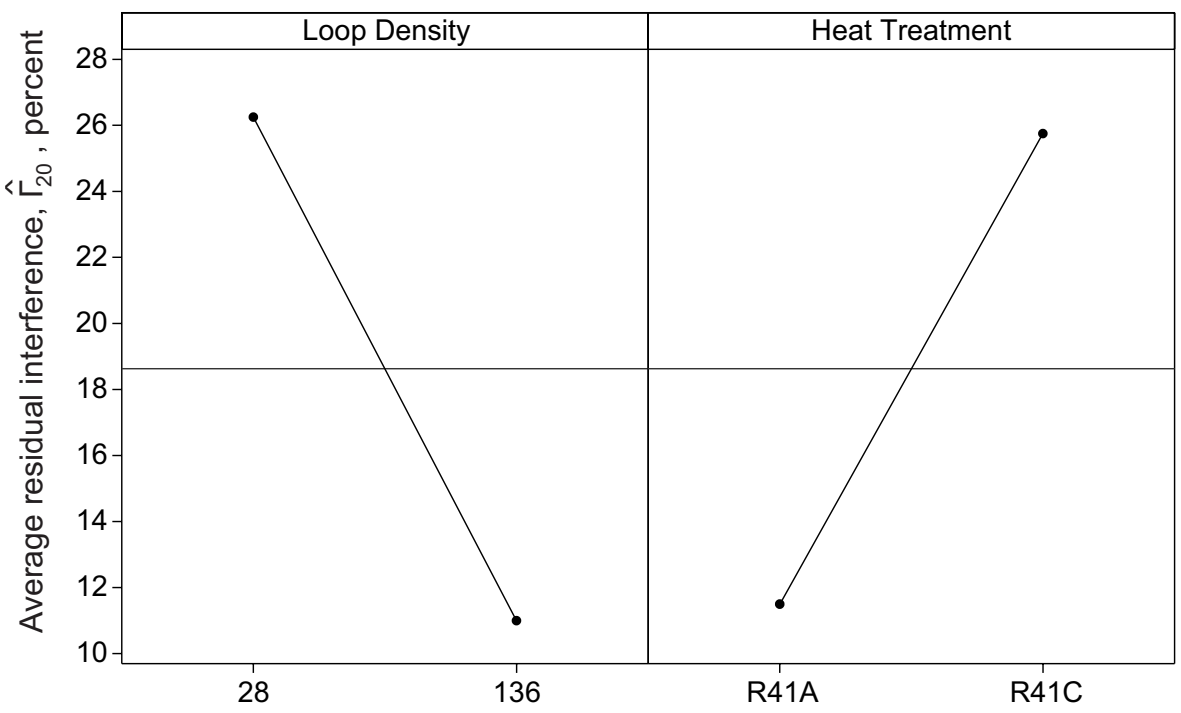

Figure 13. Effects plot showing the impact of loop density and heat treatment on average resiliency at the start of compression cycle 20 at $1750{ }^{\circ} \mathrm{F}$.

Heat treatment of the spring tube specimens using the new 5950-R41C heat treatment has a positive 
effect on cycle 20 residual interference (Figure 13). Samples heat treated using the R41C treatment show a resiliency improvement of more than $2 \mathrm{x}$ when compared to samples subjected to the 5950-R41A heat treatment.

Although interaction effects between heat treatment and loop density are not statistically significant, examination of the interaction plot in Figure 14 shows that the highest cycle 20 residual interference within the evaluated range of factor levels is achieved with the combination of heat treatment 5950-R41C and a 28 loop density.

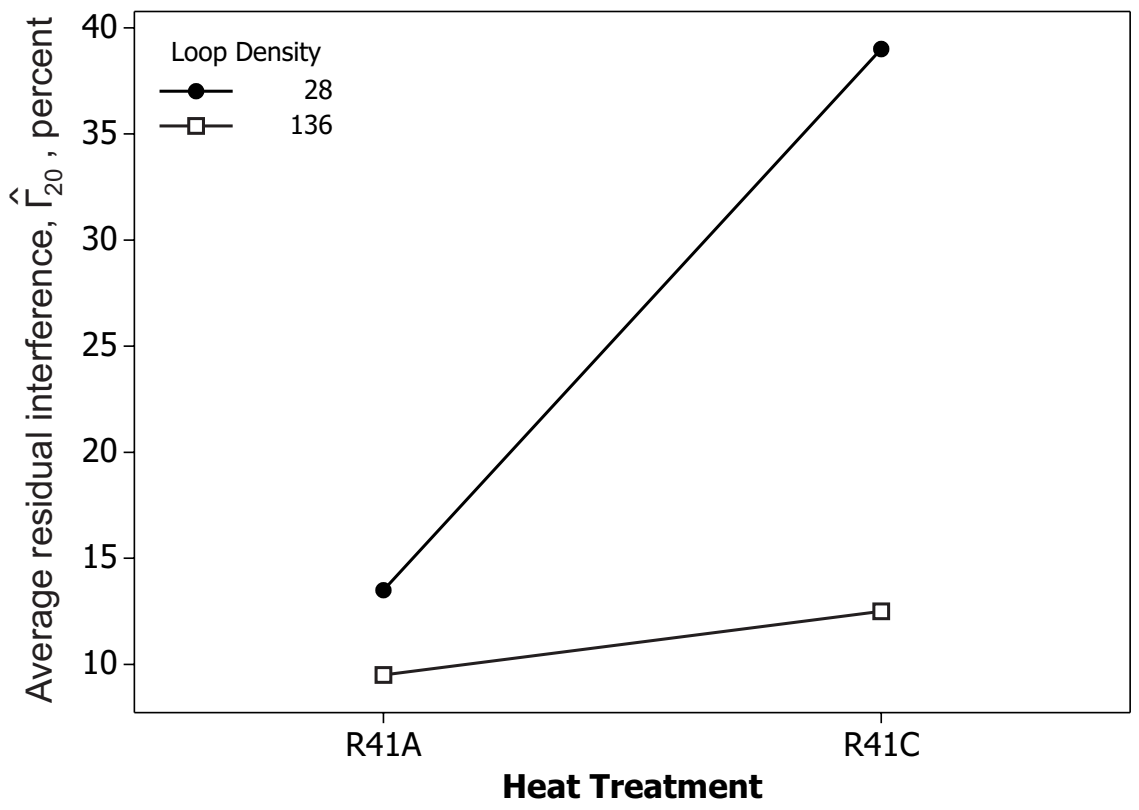

Figure 14. Effects plot showing the impact of loop density-heat treatment interaction on average resiliency at $1750{ }^{\circ} \mathrm{F}$.

Heat treatment, loop density, and their corresponding interaction have a statistically significant effect on average peak load during compression cycle 20. As shown in Figure 15, increasing loop density from 28 to 136 doubles peak load, and heat treatment R41C produces an average cycle 20 peak load $1.5 \mathrm{x}$ higher than the R41A treatment. Increasing loop density increases the amount of wire knitted into the spring tube design. This leads to higher sample stiffness and elevated peak loads. Improved creep resistance through heat treatment $\mathrm{R} 41 \mathrm{C}$ prevents load relaxation in the spring tube during cycling, which explains the higher observed cycle 20 loads with the substitution of heat treatment R41C for R41A. Although increasing resiliency is of primary interest, these analyses show that the best factor combination (of the factor levels evaluated in this grouping) for spring tube load retention during cycle 20 at $1750^{\circ} \mathrm{F}$ is a $136 \mathrm{LD}$ design with the R41C heat treatment. This is highlighted in the interaction plot presented in Figure 16. 


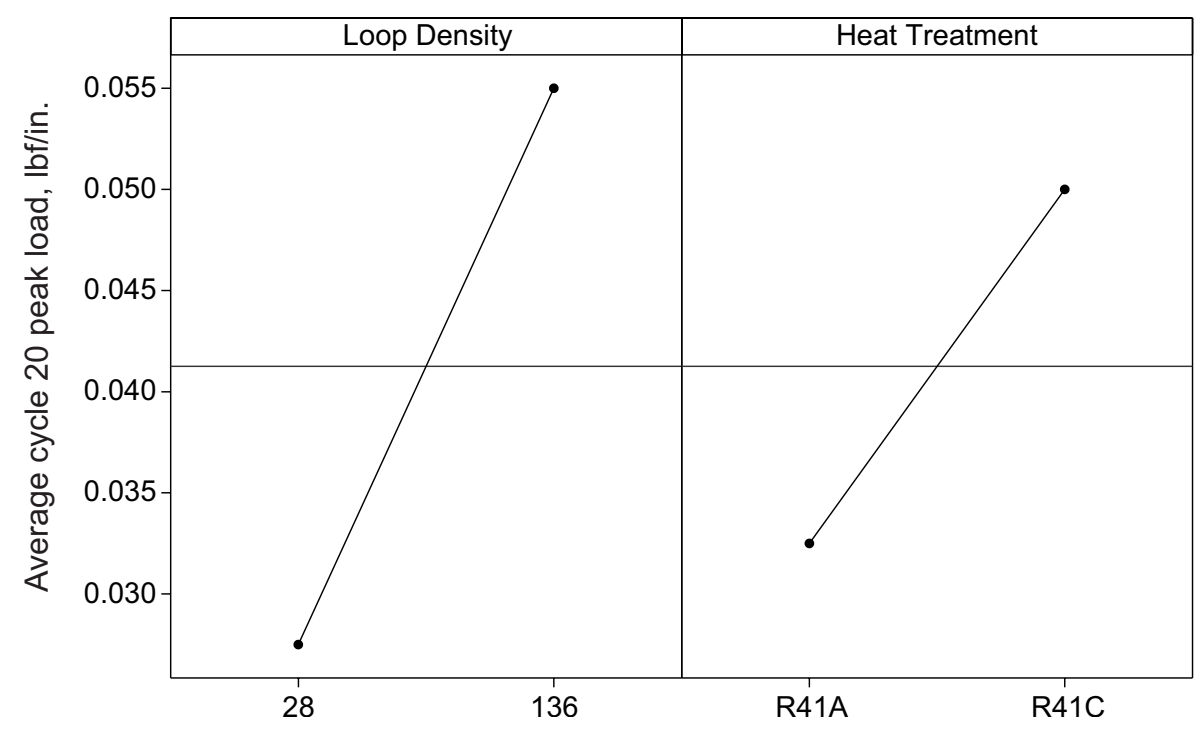

Figure 15. Effects plot showing the impact of loop density and heat treatment on cycle 20 peak load at 1750 ${ }^{\circ} \mathbf{F}$.

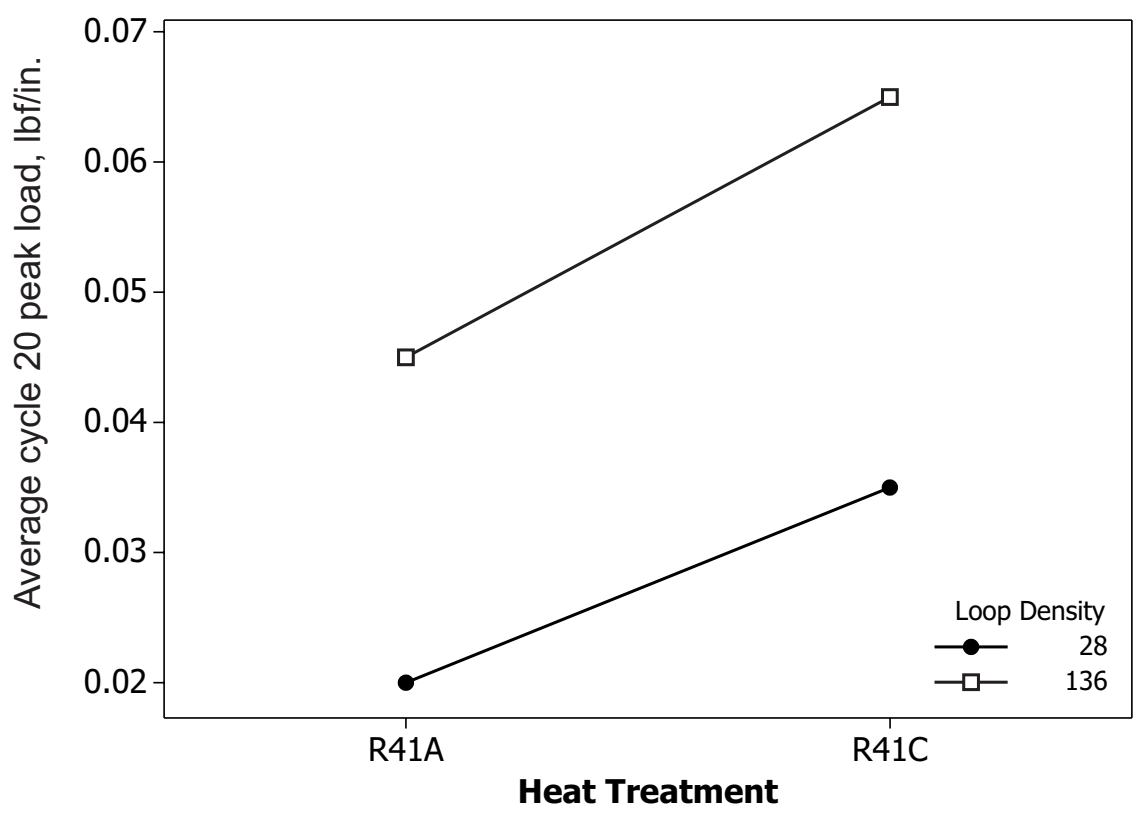

Figure 16. Effects plot showing the impact of loop density-heat treatment interaction on cycle 20 peak load at $1750{ }^{\circ} \mathbf{F}$.

\section{Heat Treatment and Wire Diameter Effects}

Statistical evaluation of cycle 20 peak load and residual interference values shows that heat treatment, wire diameter, and their corresponding interaction have a significant influence on both response variables. As shown on the effects plot in Figure 17, spring tubes fabricated using 0.009 in. dia. wire have a cycle 20 resiliency approximately $24 \%$ higher than those fabricated from the 0.005 in. dia. wire. Figure 17 also shows that samples heat treated using the 5950-R41C heat treatment maintain an average residual interference $58 \%$ higher than samples heat treated according to the R41A specification. Despite the trend highlighted 
on the main effects plot which shows a moderate resiliency improvement with the larger 0.009 in. dia. wire, examination of the interaction plot presented in Figure 18 shows that within the factor levels evaluated here, the highest cycle 20 resiliency is achieved by combining the $0.005 \mathrm{in}$. dia. wire and the R41C heat treatment.

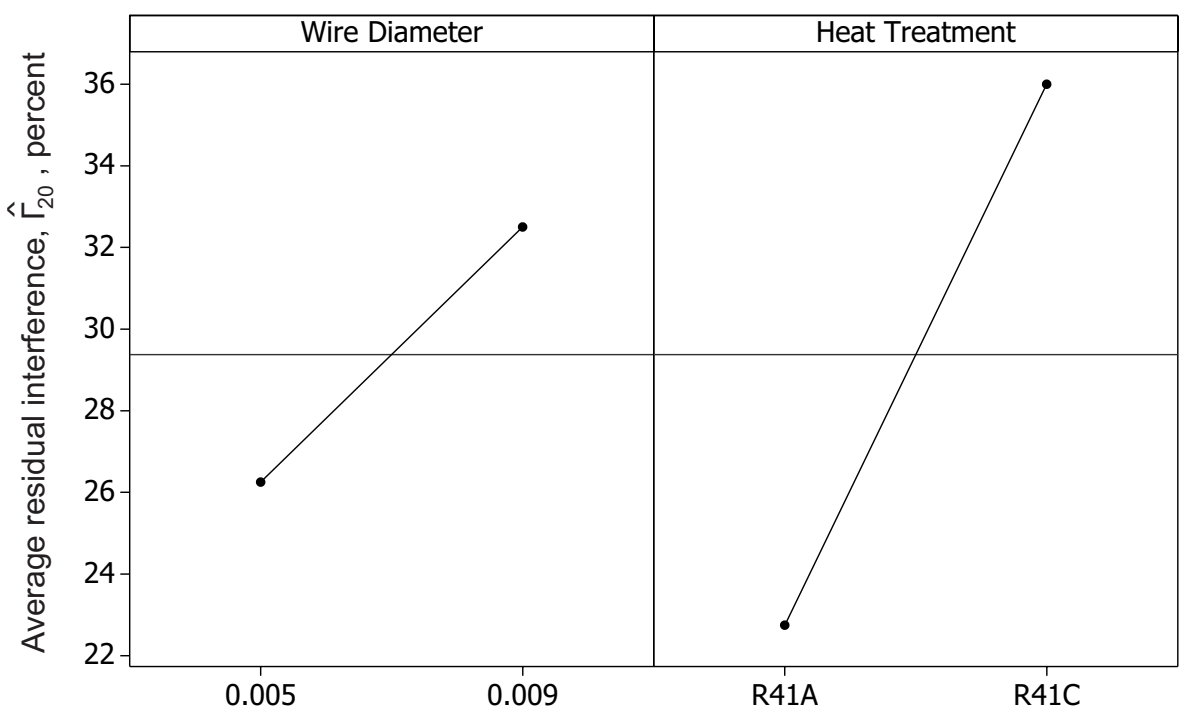

Figure 17. Effects plot showing the impact of wire diameter and heat treatment on average resiliency at the start of cycle 20 at $1750{ }^{\circ} \mathrm{F}$.

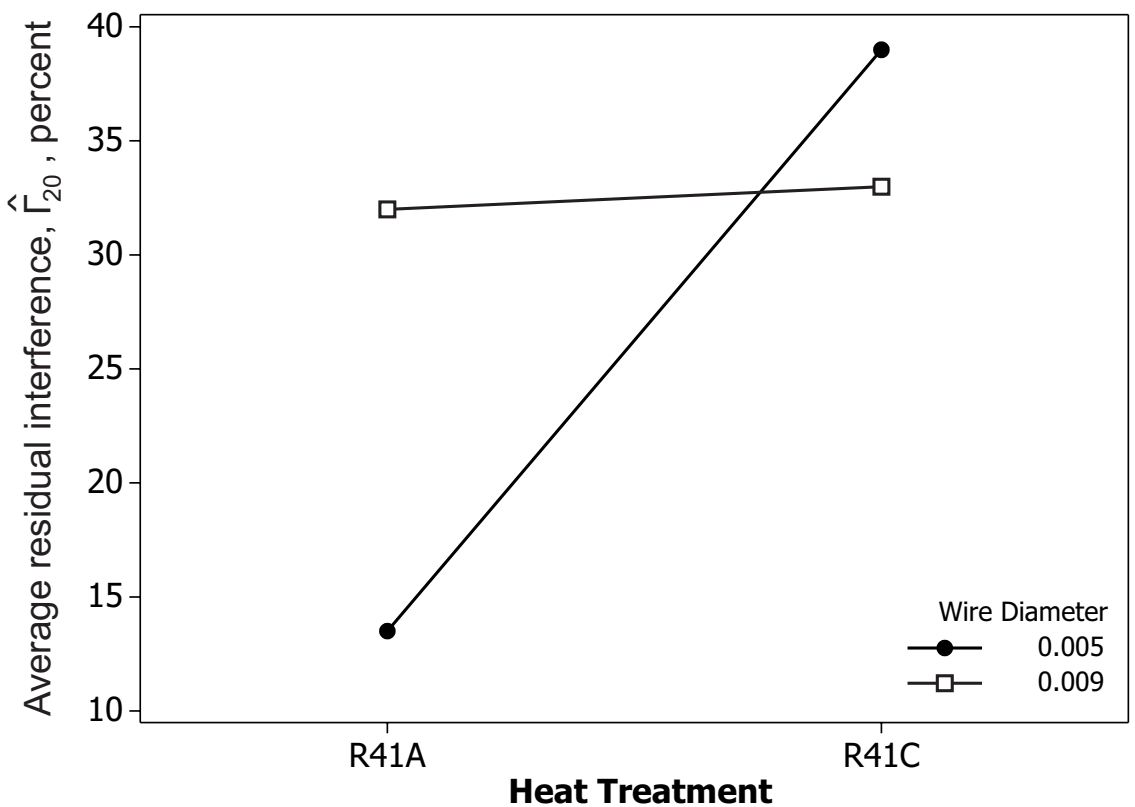

Figure 18. Effects plot showing the influence of wire diameter-heat treatment interaction on average resiliency at the start of cycle 20 at $1750{ }^{\circ} \mathrm{F}$.

Wire diameter has a much more pronounced effect on peak load than it does on resiliency. As shown in Figure 19, the larger 0.009 in. dia. wire produces loads approximately 9 times higher than the 0.005 in. dia. wire. Heat treatment in this paired evaluation does not have the same impact on load that was observed in previous comparisons. Heat treatment using the $\mathrm{R} 41 \mathrm{C}$ specification produces a small decrease in peak 
load of approximately $8.5 \%$. This decrease may be an artifact of alloy overaging which is discussed in the "Limitations of Heat Treatment Effects" section. The plot of heat treatment and wire diameter interaction presented in Figure 20 shows that if optimizing peak load is of interest, the best combination of factor levels in this set for the highest cycle 20 peak load is 0.009 in. dia. wire and the R41A heat treatment.

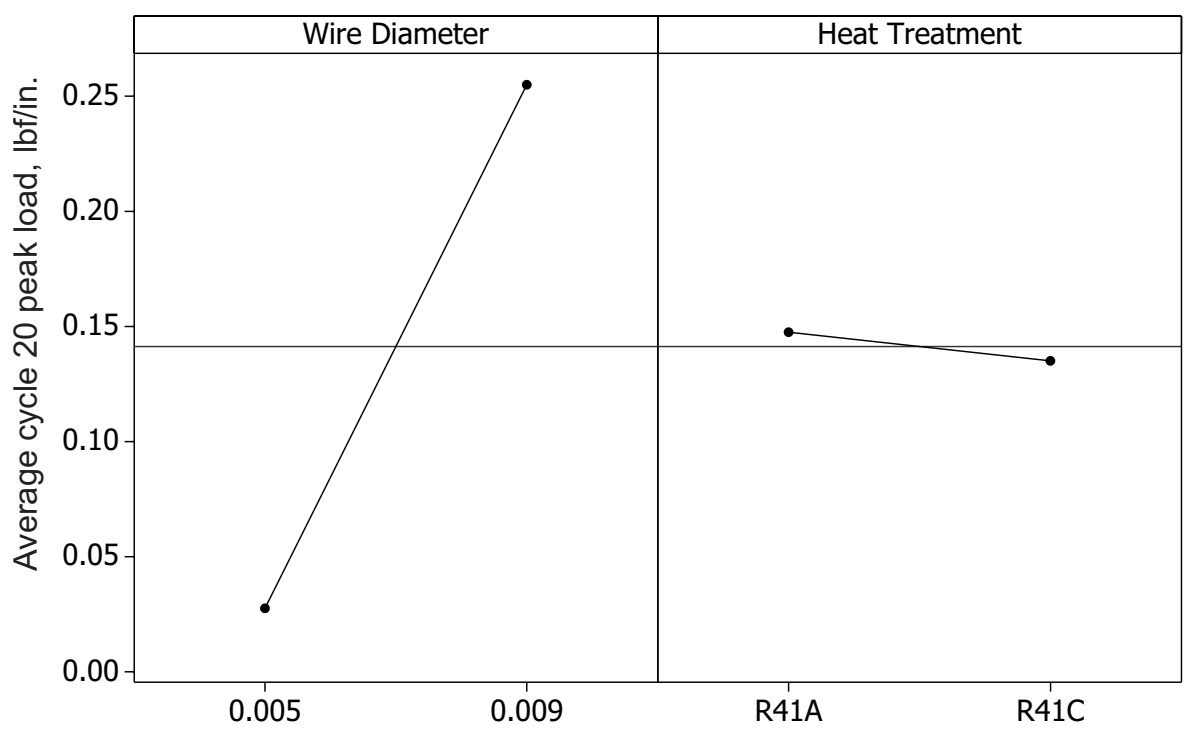

Figure 19. Effects plot depicting the impact of wire diameter and heat treatment on cycle 20 peak load at $1750{ }^{\circ} \mathbf{F}$.

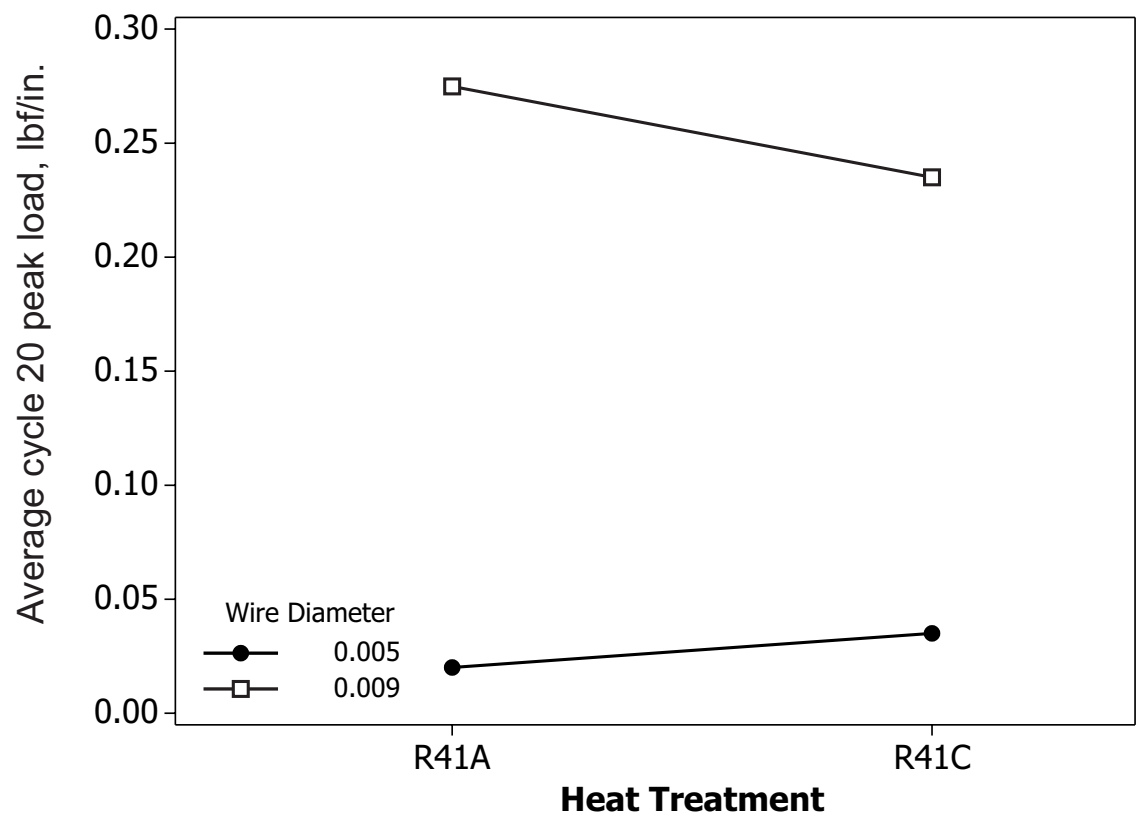

Figure 20. Effects plot illustrating the impact of wire diameter-heat treatment interaction on cycle 20 peak load at $1750{ }^{\circ} \mathrm{F}$. 


\section{Limitations of Heat Treatment Effects}

At $1750{ }^{\circ} \mathrm{F}$, it is likely that much of the benefit gained through heat treatment of the Rene 41 alloy (improved yield and creep strength) is relieved due to further microstructural changes that occur within the material when it is exposed to elevated test temperatures for extended time periods during test rig heatup. Based on this hypothesis, test results are conservative, and the evaluated spring tubes would likely perform better in actual flight conditions where an extended high temperature "soaking" of the seal is not an issue because peak heating times during re-entry are significantly shorter than the time required for test rig heatup. The 5950-R41C heat treatment is designed to promote the growth of intragranular gamma prime precipitates during aging and thus improve the high temperature strength of the Rene 41 alloy by impeding dislocation movement. Further exposure to elevated temperatures for extended time periods (e.g., during rig heatup) can result in overaging of the material. Overaging occurs when the gamma prime precipitates grow too large and lose their ability to prevent dislocation motion. This phenomenon can counteract any improvements previously imposed on the aged alloy and leave material properties comparable to those produced by the original R41A heat treatment. Even so, examination of the trends highlighted in Figure 21 shows that heat treatment R41C improves average cycle 20 residual interference by approximately $54 \%$. This analysis (one-way ANOVA) differs from previous analyses $\left(2^{2}\right.$ full factorial ANOVA using factor pairs) in that it combines test data from all three knit geometries to gauge the influence of heat treatment on spring tube performance. Results obtained through this analysis are consistent with those from the pair-wise analyses presented previously.

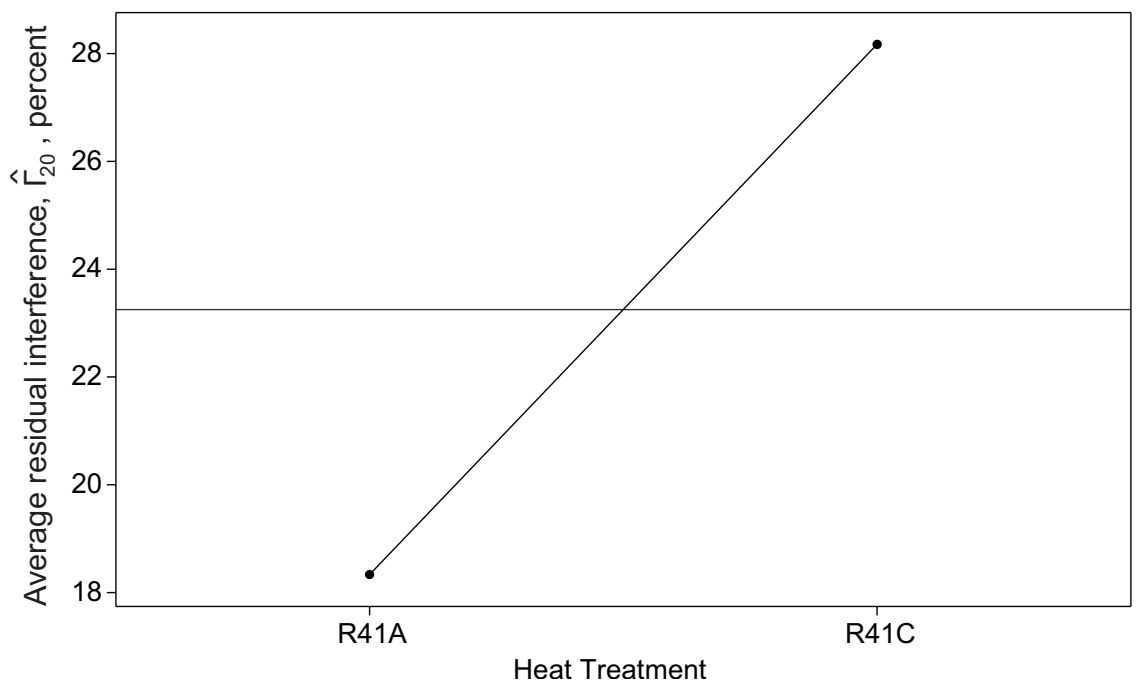

Figure 21. Effects plot showing the influence of heat treatment only on average spring tube resiliency at the start of cycle 20 at $1750{ }^{\circ} \mathrm{F}$.

\section{Conclusions}

The baseline control surface seal does not satisfy the stringent design requirements for use on future space vehicles. Limits in high temperature seal resiliency observed during laboratory testing could lead to leakage of damaging hot gases past the seal during re-entry, exposing critical underlying system components to excessive temperatures. High temperature compression testing shows that seal resiliency can be enhanced by improving the spring tube component. After testing on the spring tube itself, the following conclusions are drawn:

1. Creep is the dominant deformation mechanism driving spring tube resiliency loss at elevated test temperatures. At $1750{ }^{\circ} \mathrm{F}$, Rene 41 ST-5 spring tubes (NASA 5950-R41A heat treatment) evaluated with the modified compression test method using increased load/unload rates without dwell periods 
show a calculated cycle 10 resiliency $2.1 \mathrm{x}$ higher than identical spring tubes examined using the standard compression test procedure. This margin increases to $2.5 \mathrm{x}$ at the start of cycle 20 in those tests. Additional spring tube improvements may be obtained through further material substitution of alloys that would provide enhanced creep resistance (e.g., oxide dispersion strengthened alloys).

2. DOE analysis shows that spring tube performance improvements realized in earlier tests through substitution of heat treated Rene 41 alloy (NASA 5950-R41A heat treatment) for the baseline Inconel X-750 material can be further extended through modified thermal processing. The NASA 5950-R41C heat treatment, designed to enhance the creep strength of Rene 41, produces a cycle 20 resiliency increase (at $1750{ }^{\circ} \mathrm{F}$ ) of approximately $54 \%$ over samples processed according to the R $41 \mathrm{~A}$ specification.

3. Increasing loop density from 28 to 136 loops/in. ${ }^{2}$ produces a resiliency decay of $58 \%$ at the start of cycle 20 at $1750{ }^{\circ} \mathrm{F}$. Previous testing of Inconel X-750 samples at $1500{ }^{\circ} \mathrm{F}$ shows a slight resiliency improvement when loop density is increased from 34 to 64 loops/in. ${ }^{2}$. This suggests that an optimal loop density may exist between 28 and 136 that could further enhance spring tube performance.

4. As a main effect, increasing wire diameter from 0.005 in. to 0.009 in. improves cycle 20 resiliency at $1750{ }^{\circ} \mathrm{F}$ by $24 \%$. However, when the effect of wire diameter is examined in combination with heat treatment interaction, spring tubes fabricated from 0.005 in. dia. wire appear to be marginally better. Despite this, samples made from $0.009 \mathrm{in}$. dia. wire are preferred because the loads produced by 0.005 in. wire spring tubes are so small that the samples would likely be inadequate for use as seal preloading elements.

5. Based on the factors and levels considered herein, the best combination for extending high temperature performance over the baseline Inconel X-750 spring tube is a $28 \mathrm{LD}$ spring tube fabricated from 0.009 in. dia. Rene 41 wire and heat treated to the NASA 5950-R41C specification. Because the improved design is geometrically equivalent to the baseline spring tube, the benefits of enhanced high temperature resiliency can be immediately realized by directly incorporating this new design into existing seal applications.

\section{References}

\footnotetext{
${ }^{1}$ Dunlap, P.H., Steinetz, B.M., Curry, D.M., DeMange, J.J., Rivers, H.K., and Hsu, S.Y., "Investigations of Control Surface Seals for Re-Entry Vehicles," NASA/TM-2002-211708, July 2002.

${ }^{2}$ Knitted Wire Spring Specification, Specification Number MB0160-047, Revision D, The Boeing Company, Huntington Beach, April 2001.

${ }^{3}$ Aerospace Material Specification, AMS 5698G, January 2003.

${ }^{4}$ Dunlap, P.H., Steinetz, B.M. and Curry, D.M., "Rudder/Fin Seal Investigations for the X-38 Re-Entry Vehicle," NASA/TM-2000-210338/REV1, AIAA—2000-3508, November 2000.

${ }^{5}$ DeMange, J.J., Dunlap, P.H., and Steinetz, B.M., "Advanced Control Surface Seal Development for Future Space Vehicles," NASA/TM-2004-212898, January 2004.

${ }^{6}$ Taylor, S.C., DeMange, J.J., Dunlap, P.H., and Steinetz, B.M., "Evaluation of High Temperature Knitted Spring Tubes for Structural Seal Applications," NASA/TM—2004-213183, AIAA—2004-3890, September 2004.

${ }^{7}$ Dunlap, P.H., Steinetz, B.M., DeMange, J.J., and Taylor, S.C., "Toward an Improved Hypersonic Engine Seal," NASA/TM-2003-212531, AIAA-2003-4834, July 2003.

${ }^{8}$ Taylor, S.C., "Evaluation of High Temperature Knitted Spring Tubes for Structural Seal Applications," Case Western Reserve University, 2005.

9 "Standard Test Methods for Determining Average Grain Size," ASTM E112-96, July 1996.

${ }^{10}$ Oswald, J.J., "Modeling and Evaluation of Canted Coil Springs and Knitted Spring Tubes As High Temperature Seal Preload Devices," Case Western Reserve University, 2005.

11 "Material Technical Data Sheet, Rene 41," High Temp Metals, Inc.

${ }^{12}$ Knopp, W.D., "Aerospace Structural Metals Handbook". West Lafayette: Purdue Research Foundation, 1994.

${ }^{13}$ Montgomery, D.C., "Design and Analysis of Experiments". New York: John Wiley and Sons, Inc., 2001.
} 


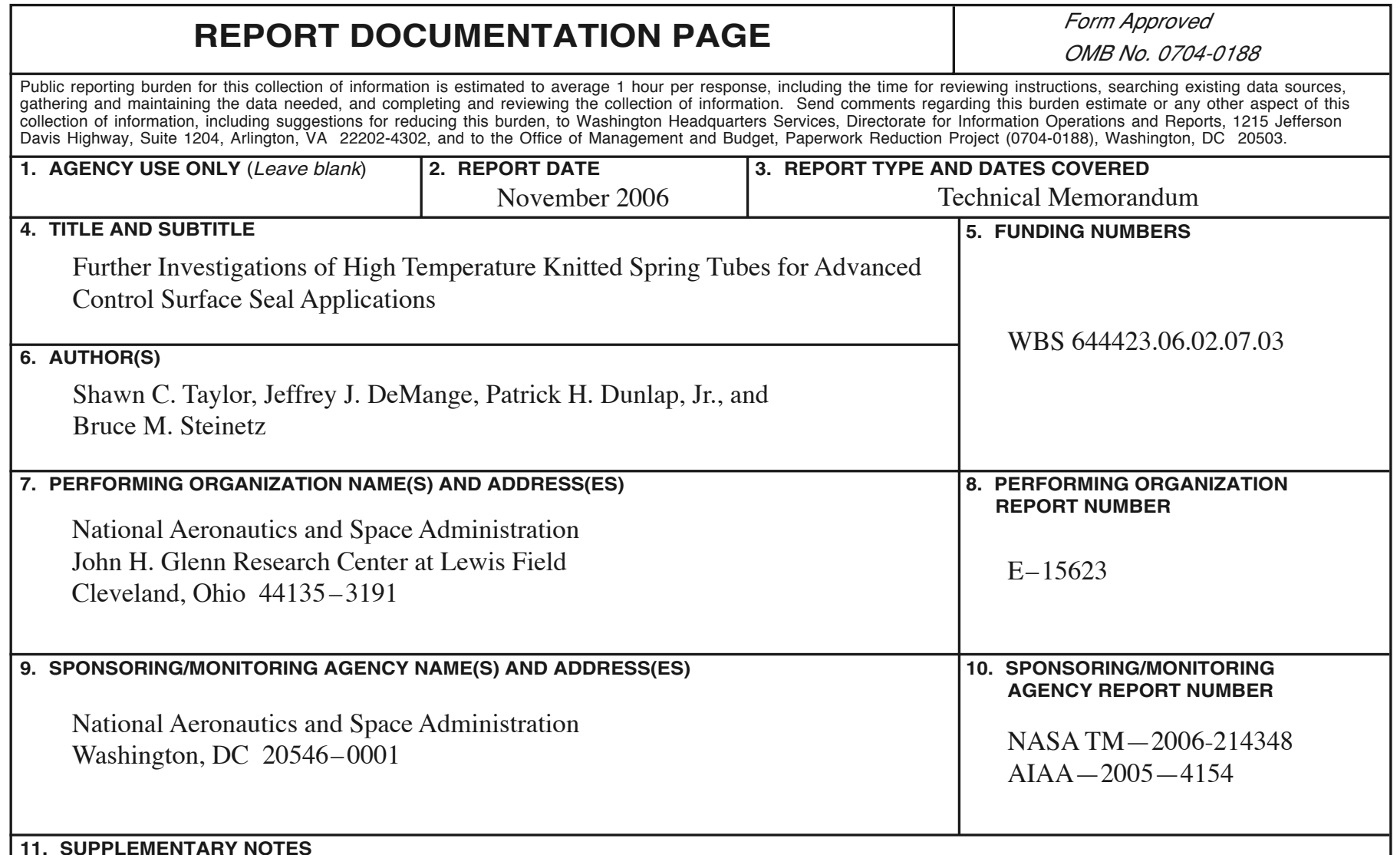

\section{SUPPLEMENTARY NOTES}

Prepared for the 41st Joint Propulsion Conference and Exhibit cosponsored by the AIAA, SAE, ASME, and ASEE, Tucson, Arizona, July 10-13, 2005. Shawn C. Taylor and Jeffrey J. DeMange, University of Toledo, 2801 W. Bancroft St., Toledo, Ohio 43606; Patrick H. Dunalp, Jr. and Bruce M. Steinetz, Glenn Research Center. Responsible person, Shawn C. Taylor, organization code RXM, 216-433-3166.

12a. DISTRIBUTION/AVAILABILITY STATEMENT 12b. DISTRIBUTION CODE

Unclassified - Unlimited

Subject Category: 37

Available electronically at http://gltrs.grc.nasa.gov

This publication is available from the NASA Center for AeroSpace Information, 301-621-0390.

13. ABSTRACT (Maximum 200 words)

Knitted metallic spring tubes are the structural backbones that provide resiliency in control surface seals for use on current and future reusable space launch vehicles. Control surface seals fill the space between movable control surfaces such as body flaps, rudders and elevons, and the static body structures to which they are attached. These seals must remain in continuous contact with opposing surfaces to prevent the ingestion of damaging hot gases encountered during atmospheric re-entry. The Inconel X-750 (Special Metals Corporation) spring tube utilized in the baseline control surface seal shows significant resiliency loss when compressed at temperatures as low as $1200^{\circ} \mathrm{F}$. High temperature compression testing and microstructural analysis show that creep is the dominant deformation mechanism leading to permanent set and resiliency loss in tested spring tube samples. Additional evaluation using a structured design of experiments approach shows that spring tube performance, primarily high temperature resiliency, can be enhanced through material substitution of Rene 41 (Allvac) alloy (for the baseline Inconel X-750 material) when coupled with specialized thermal processing.

\section{SUBJECT TERMS}

Seals; Resiliency; Design; Test; High temperature

\begin{tabular}{|c|c|c|}
\hline $\begin{array}{c}\text { 17. SECURITY CLASSIFICATION } \\
\text { OF REPORT } \\
\text { Unclassified }\end{array}$ & $\begin{array}{c}\text { 18. SECURITY CLASSIFICATION } \\
\text { OF THIS PAGE } \\
\text { Unclassified }\end{array}$ & $\begin{array}{c}\text { 19. SECURITY CLASSIFICATION } \\
\text { OF ABSTRACT } \\
\text { Unclassified }\end{array}$ \\
\hline
\end{tabular}



